\title{
Diffusivity of Carbon Dioxide through the Skin and Flesh of 'Russet Burbank' Potato Tubers
}

\author{
Aref A. Abdul-Baki ${ }^{1}$ \\ U.S. Department of Agriculture, Agricultural Research Service, Plant Sciences Institute, Vegetable \\ Laboratory, Beltsville Agricultural Research Center, Beltsville, MD 20705-2350 \\ Theophanes Solomos ${ }^{2}$ \\ Department of Horticulture, University of Maryland, College Park, MD 20742-5611
}

Additional index words. diffusion barriers, flux, respiration, heat stress

\begin{abstract}
The diffusion coefficient of $\mathrm{CO}_{2}$ in 'Russet Burbank' potato (Solanum tuberosum L.) tubers was determined under steady-state conditions at 10 and $27 \mathrm{C}$. The data showed that the skin is the main barrier to gas diffusion, with an average diffusion coefficient of $6.57 \times 10^{-7}$ and $7.61 \times 10^{-7} \mathrm{~cm} \cdot \mathrm{s}^{-1}$ at 10 and $27 \mathrm{C}$, respectively. The flesh also presents an appreciable barrier to gas diffusion. The average diffusion coefficient of $\mathrm{CO}_{2}$ in the flesh was $2.00 \times 10^{-4}$ and $2.24 \times 10^{-4}$ $\mathrm{cm} \cdot \mathrm{s}^{-1}$ at 10 and $27 \mathrm{C}$, respectively. Under regular storage conditions, the tuber is well aerated and the concentration of $\mathrm{O}_{2}$ at the center of the tuber is sufficient to maintain aerobic respiration.
\end{abstract}

The diffusion of $\mathrm{O}_{2}$ into the internal atmosphere of potato tubers has been the subject of considerable investigation because of concerns regarding its effects on sprouting (Banks and Kays, 1988; Brändle, 1968; Burton, 1950; Woolley, 1962). The intercellular spaces of potato tubers are small (Burton, 1950; Woolley, 1962), a fact that should appreciably limit the diffusion of gases to the center of the tuber. However, it was shown previously that, at regular storage temperatures, the intercellular spaces contain sufficient $\mathrm{O}_{2}$ concentrations because of low respiratory activity (Burton, 1950; James, 1953; Solomos and Laties, 1975). Under adverse conditions of temperature and soil moisture, however, a partial anoxic environment may prevail at the center of the tuber.

In previous work, the diffusivities of gases through the skin and flesh were determined separately (Banks and Kays, 1988; Burton, 1950; Woolley, 1962). The permeability of gases through the flesh has been carried out in tissue segments. Because of the well-known effects of wounding on the rate of $\mathrm{O}_{2}$ uptake and the flooding of the intercellular spaces of the cut surfaces (Laties, 1978; Woolley, 1962), this method may introduce uncertainties concerning the accuracy of gas diffusivities through the flesh.

In the present work, we have estimated the diffusivity of $\mathrm{CO}_{2}$ in the skin and flesh of 'Russet Burbank' potato tubers. To ascertain the validity of the results, we determined the diffusion coefficient of $\mathrm{CO}_{2}$ at two temperatures and used the results at one temperature to calculate either respiration or internal $\mathrm{CO}_{2}$ concentration at the second temperature.

\section{Materials and Methods}

'Russet Burbank' potato tubers were purchased from the local supermarket, washed, and stored at 10C for $24 \mathrm{~h}$. Tubers were selected whose geometry most closely conformed to that of a cylinder, i.e., each tuber had a diameter that was uniform along its length. Despite these precautions, however, it was not easy to find tubers with an ideal cylindrical shape.

Received for publication 4 Aug. 1993. Accepted for publication 6 Jan. 1994. The cost of publishing this paper was defrayed in part by the payment of page charges. Under postal regulations, this paper therefore must be hereby marked advertisement solely to indicate this fact.

${ }^{1}$ Research plant physiologist.

${ }^{2}$ Professor.
Determining $\mathrm{CO}_{2}$ and $\mathrm{O}_{2}$ concentrations in intercellular spaces. The concentrations of $\mathrm{CO}_{2}$ and $\mathrm{O}_{2}$ in the internal atmosphere of potato tubers were determined by modifying the method first introduced by Wardlaw and Leonard (1939). Two chromatographic septa were affixed to the tuber surface with either an epoxy resin or Elmer's glue at a $90^{\circ}$ angle to each other at the midpoint of the tuber. Two 15-gauge, 12.5-cm-long hypodermic needles were inserted through the septa, one into the center and the other under the skin of the tuber, and then pulled back very slightly to create a small cavity. The volume of the needles was determined by attaching them to a syringe and filling them with water. The needle was inserted into a rubber stopper and the syringe was then detached and the hub was sealed with the vaccine cap into which a small needle was inserted to remove the water that was displaced by the cap. The volume of the needles was $\approx 200 \mathrm{~mm}^{3}$. A stainlesssteel wire was inserted into the needle during the insertion to prevent needle clogging. The tuber was turned over to drain any liquid that might have been produced by the wounding. The hub of the needle was sealed with a vaccine cap. The tubers were left at $10 \mathrm{C}$ for 48 to $72 \mathrm{~h}$ to recover from the wounding. With time, the gas composition within the needle is expected to come to equilibrium with that of the adjacent intercellular spaces. The concentration of $\mathrm{CO}_{2}$ inside the needle was determined by withdrawing $50-\mathrm{mm}^{3}$ gas samples with a $0.5-\mathrm{cm}^{3}$ airtight syringe fitted with a 26-gauge needle for $\mathrm{CO}_{2}$ and $100-\mathrm{mm}^{3}$ samples for $\mathrm{O}_{2}$. Carbon dioxide and $\mathrm{O}_{2}$ were analyzed using a Carle (Tulsa, Okla.) gas chromatograph equipped with a thermal conductivity detector and fitted with activated alumina and molecular sieve columns for separating $\mathrm{CO}_{2}$ and $\mathrm{O}_{2}$, respectively. The $\mathrm{O}_{2}$ values were corrected for the presence of Ar. The composition of air was assumed to contain 21.218 and $0.955 \mathrm{kPa}$ of $\mathrm{O}_{2}$ and Ar, respectively. Sampling was carried out at 3 - to 4 -h intervals for 2 weeks. At the end of the experiment, the tubers were cut along the scar created by the needles to determine the precise length of insertion and to inspect for visual symptoms of microbial contamination. The rate of $\mathrm{CO}_{2}$ evolution was determined under static conditions by enclosing the tuber in an $870-\mathrm{cm}$ air-tight jar until the concentration of $\mathrm{CO}_{2}$ increased to $\approx 0.303 \mathrm{kPa}$. The headspace air was mixed and $1-\mathrm{ml}$ aliquots were injected into the gas chromatograph. All experiments were repeated at least twice using seven to nine tubers per experiment.

Determining skin thickness. Skin (phellem) thickness was determined by preparing thin slices of the tuber using a sharp razor 
blade. The slice, which included the skin, was mounted on a glass slide and washed several times with deionized water to remove the loose starch. Skin thickness was measured using a Diphot-TMD inverted microscope (Nikon, Image Systems, Columbia, Md.) equipped with a reticle built into the eyepiece (Klarmann and Rulings, Manchester, N.H.) and a camera. About 60 measurements were made on four slices taken from random locations on the tuber surface.

Determining the diffusion coefficient of $\mathrm{CO}_{2}$. Previous work has shown that gas exchange in fruit and other bulky organs can be approximated by Fick's first law of diffusion (Burg and Burg, 1965). This law states that the flux of a gas, diffusing normal to a barrier, depends on the diffusion coefficient, concentration gradient, and area (Crank, 1970; Jacobs, 1967):

where $\mathrm{J}\left(\mu \mathrm{mol} \cdot \mathrm{s}^{-1}\right)$ is the flux of the gas through the organ; $\mathrm{A}\left(\mathrm{cm}^{2}\right)$ is the area of the barrier; $\mathrm{D}\left(\mathrm{cm}^{2} \cdot \mathrm{s}^{-1}\right)$ is the diffusion coefficient; and $\mathrm{dc} / \mathrm{dx}\left(\mu \mathrm{mol} \cdot \mathrm{cm}^{-3} \cdot \mathrm{cm}^{-1}\right)$ is the concentration gradient with distance. To determine $\mathrm{D}, \mathrm{dc} / \mathrm{dx}$ must first be calculated.

In Eq. [1], dc/dx frequently is replaced by $\Delta c / \Delta x$. This replacement is permissible only if the change in concentration is linear with distance and if the barrier is either a metabolically inert plane or a hollow spherical shell (Jacobs, 1967; Nobel, 1983; Solomos, 1987). The concentration gradient is determined by solving Fick's equation for the second law of diffusion (Crank, 1970; Jacobs, 1967).

For a metabolically active cylinder under steady-state conditions, Fick's equation for the second law of diffusion is (Crank, 1970; Hill, 1928; Jacobs, 1967)

where $\mathrm{v}\left(\mu \mathrm{mol} \cdot \mathrm{cm}^{-3} \cdot \mathrm{s}^{-1}\right)$ is the specific rate of $\mathrm{CO}_{2}$ production, $\mathrm{r}$ $(\mathrm{cm})$ is the radius, and $\mathrm{D}\left(\mathrm{cm}^{2} \cdot \mathrm{s}^{-1}\right)$ is the diffusion coefficient.

The skin of the potato tuber is treated as a hollow metabolically inert cylindrical shell, with $r_{o}$ and $r_{i}$ being the outside and inside radii of the cylindrical shell, respectively. The flux of $\mathrm{CO}_{2}$ through such a cylindrical shell is given by Crank (1970): where $\mathrm{h}(\mathrm{cm})$ is the length of the cylinder; $\mathrm{C}_{\mathrm{u}}$ and $\mathrm{C}_{\text {out }}$ are the concentrations of $\mathrm{CO}_{2}$ in $\left(\mu \mathrm{mol} \cdot \mathrm{cm}^{-3}\right)$ under the skin and in the external ambient atmospheres, respectively; and $r_{0}$ and $r_{i}(\mathrm{~cm})$ are the outside and inside radii of the cylindrical shell. In other words, $r_{o}-r_{i}$ is the thickness of the skin.

It should be kept in mind that the above equations are only an approximation because the geometrical shape of the tuber is not a perfect cylinder and that the diffusion takes place through a perforated cylindrical shell and not the whole surface.

The diffusivity of the flesh of 'Russet Burbank' tubers is calculated by treating the tuber as a metabolically active solid cylinder. The concentration of $\mathrm{CO}_{2}$ along the radius of the tuber is obtained from the solution of Eq. [4] (Hill, 1928):

where $r_{i}(\mathrm{~cm})$ is the inside radius of the tuber and $\mathrm{C}_{\mathrm{u}}\left(\mu \mathrm{mol} \cdot \mathrm{cm}^{-3}\right)$ is the concentration of $\mathrm{CO}_{2}$ under the skin.

Thus, assuming that the rate of $\mathrm{CO}_{2}$ evolution is uniform throughout the cylinder, the concentration of $\mathrm{CO}_{2}$ at the center, $\mathrm{r}=$ 0 , of the tuber is

\section{Results}

The accurate determination of gas diffusivity through the tuber critically depends on the precision of gas analyses along the radius of the tuber. Previous techniques for determining the gas composition in the intercellular spaces are not suitable for routine analyses involving several tubers (Solomos, 1987). The present method allows multiple sampling of the same tuber over several days. It is expected that, with time, the gas in the needle $\left(\approx 200 \mathrm{~mm}^{3}\right)$ will be in equilibrium with that of the tissue (Burg and Burg, 1965).

Previous work indicated that, in apples, the internal pressure is similar to that of the ambient atmosphere (Hulme, 1951). Since $\mathrm{O}_{2}$

Table 1. Partial pressures of $\mathrm{O}_{2}$ and $\mathrm{CO}_{2}$ at the center of the tuber. ${ }^{\mathrm{z}}$

\begin{tabular}{|c|c|c|c|c|}
\hline \multirow[b]{2}{*}{ Tuber } & $\mathrm{O}_{2}$ & $\mathrm{CO}_{2}$ & $\mathrm{CO}_{2}+\mathrm{O}_{2}$ & \multirow[b]{2}{*}{$\operatorname{DIF}^{y}(\%)$} \\
\hline & \multicolumn{3}{|c|}{$(\mathrm{kPa})$} & \\
\hline \multicolumn{5}{|c|}{$18 \mathrm{C}$} \\
\hline 1 & $16.07(0.60)$ & $4.47(0.05)$ & 20.54 & 97.27 \\
\hline 2 & $16.23(2.35)$ & $3.42(0.19)$ & 19.65 & 92.61 \\
\hline 3 & $16.69(1.14)$ & $3.58(0.46)$ & 20.27 & 95.52 \\
\hline 4 & $16.66(0.14)$ & $5.16(0.24)$ & 21.82 & 102.83 \\
\hline 5 & $16.53(0.46)$ & $4.25(0.31)$ & 20.78 & 97.94 \\
\hline 6 & $14.70(1.42)$ & $4.18(0.06)$ & 18.88 & 88.98 \\
\hline 7 & $16.59(1.81)$ & $4.35(0.26)$ & 20.94 & 98.75 \\
\hline \multicolumn{5}{|c|}{$26 C$} \\
\hline 1 & $10.27(0.27)$ & $9.65(0.77)$ & 19.92 & 93.88 \\
\hline 2 & $10.54(0.53)$ & $8.12(0.24)$ & 18.66 & 87.90 \\
\hline 3 & $12.40(1.32)$ & $9.03(1.33)$ & 21.43 & 100.99 \\
\hline 4 & $10.07(1.52)$ & $8.73(0.44)$ & 18.80 & 88.62 \\
\hline 5 & 11.34 (1.68) & $9.02(0.29)$ & 20.36 & 95.97 \\
\hline 6 & $9.47(0.61)$ & $8.91(0.59)$ & 18.83 & 86.60 \\
\hline 7 & $12.08(0.62)$ & $8.67(0.53)$ & 20.75 & 97.77 \\
\hline
\end{tabular}

${ }^{2}$ The values of the internal partial pressures of $\mathrm{O}_{2}$ and $\mathrm{CO}_{2}$ are the average of four and five measurements of $18 \mathrm{C}$ and $26 \mathrm{C}$, respectively. The number in parenthesis $=\mathrm{SD}$.

yPercentage DIF refers to the percentage difference between the expected and observed sum of the internal partial pressures of $\mathrm{CO}_{2}$ and $\mathrm{O}_{2}$. 
Table 2. Partial pressures ${ }^{\mathrm{z}}$ of $\mathrm{CO}_{2}$ in $\mathrm{kPa}$ at the center and under the skin of potato tubers held at 10 and 27C $($ Expt. 1).

\begin{tabular}{|c|c|c|c|c|c|c|c|}
\hline \multirow[b]{2}{*}{ Tuber } & \multirow{2}{*}{$\begin{array}{c}\text { Fresh } \\
\text { wt } \\
(\mathrm{g})\end{array}$} & \multicolumn{2}{|c|}{$\mathrm{kPa}$ at center at } & \multicolumn{2}{|c|}{$\mathrm{kPa}$ under skin at } & \multicolumn{2}{|c|}{$\begin{array}{l}\text { Respiration rate } \\
(\mu \mathrm{l} \mathrm{CO} / \text { g per } \mathrm{h})\end{array}$} \\
\hline & & $10 \mathrm{C}$ & $27 \mathrm{C}$ & $10 \mathrm{C}$ & $27 \mathrm{C}$ & $10 \mathrm{C}$ & $27 \mathrm{C}$ \\
\hline 1 & 363.7 & $2.63 \pm 0.30$ & $7.21 \pm 0.96$ & $1.74 \pm 0.25$ & $4.75 \pm 0.64$ & 2.29 & 6.83 \\
\hline 2 & 301.4 & $2.31 \pm 0.22$ & $5.59 \pm 0.71$ & $1.71 \pm 0.26$ & $3.55 \pm 0.76$ & 2.25 & 6.58 \\
\hline 3 & 304.5 & $2.86 \pm 0.28$ & $8.16 \pm 1.89$ & $2.23 \pm 0.34$ & $6.64 \pm 0.01$ & 2.58 & 7.21 \\
\hline 4 & 281.8 & $2.29 \pm 0.21$ & $6.15 \pm 1.49$ & $1.83 \pm 0.27$ & $4.69 \pm 1.18$ & 2.15 & 6.94 \\
\hline 5 & 285.9 & $2.22 \pm 0.30$ & $6.31 \pm 1.21$ & $1.79 \pm 0.30$ & $4.67 \pm 0.80$ & 2.25 & 6.84 \\
\hline 6 & 285.0 & $3.70 \pm 0.33$ & $9.05 \pm 0.95$ & $3.07 \pm 0.43$ & $7.42 \pm 1.29$ & 2.50 & 7.00 \\
\hline 7 & 294.0 & $2.70 \pm 0.40$ & $7.43 \pm 0.75$ & $2.31 \pm 0.36$ & $6.75 \pm 0.54$ & 2.59 & 7.25 \\
\hline 8 & 291.5 & $2.49 \pm 0.34$ & $7.33 \pm 1.72$ & $1.77 \pm 0.26$ & $5.26 \pm 0.74$ & 2.76 & 7.74 \\
\hline Average & & 2.62 & 7.15 & 2.06 & 5.44 & 2.42 & 7.05 \\
\hline
\end{tabular}

${ }^{\mathrm{z}}$ The tubers were kept at the indicated temperatures and $50 \mu \mathrm{l}$ air was removed three times daily. Respiration rate was determined under static conditions as described in material and methods.

${ }^{\mathrm{y}}$ Each number represents the average of eight measurements at $27 \mathrm{C}$ and 15 measurements at $10 \mathrm{C}( \pm \mathrm{SD})$.

is used and $\mathrm{CO}_{2}$ is produced, and since the RQ of 'Russet Burbank' potatoes is one (Solomos and Laties, 1975), it is anticipated that the sum of the internal partial pressures of $\mathrm{CO}_{2}$ and $\mathrm{O}_{2}$ will equal that of the latter in the ambient atmosphere. At 18 and $26 \mathrm{C}$, the external partial pressure of $\mathrm{O}_{2}$ was similar to the sum of the internal partial pressures of $\mathrm{CO}_{2}$ and $\mathrm{O}_{2}$ (Table 1).

It is expected that the internal concentration of $\mathrm{CO}_{2}$ would be a function of the $\mathrm{CO}_{2}$ production rate, tuber size, and permeability properties of the skin and flesh. The concentration of $\mathrm{CO}_{2}$ at the center and under the skin of tubers varied appreciably among individual tubers (Table 2). There is, however, a consistent trend. Tubers with high $\mathrm{CO}_{2}$ concentrations at the center also have high concentrations under the skin. Moreover, the trend was maintained when the tubers are transferred from 10 to $27 \mathrm{C}$. It seems that this variability reflects genuine differences in the permeability characteristics of the tubers rather than being the result of experimental techniques.

Diffusion coefficient of $\mathrm{CO}_{2}$ in the skin and flesh. The thickness of the skin was considered to be equal that of the phellem cells (Fig. 1). The thickness of this layer varied from 0.009 to $0.02 \mathrm{~cm}$, with an average of $0.012 \mathrm{~cm}$. This value closely agrees with previously published values (Burton and Spragg, 1950; Peterson et al., 1985; Woolley, 1962). The diffusion coefficient of the skin was determined from Eq. [3] by inserting the observed rates of $\mathrm{CO}_{2}$ evolution, $\mathrm{CO}_{2}$ concentration under the skin and in the ambient atmosphere $(0.0304 \mathrm{kPa})$, and the dimensions of the tubers. The average values of $\mathrm{D}_{\mathrm{CO}_{2}}$ were $6.24 \times 10^{-7}$ and $7.26 \times 10^{-7} \mathrm{~cm}^{2} \cdot \mathrm{s}^{-1}$ at 10 and $27 \mathrm{C}$, respectively, and their ratio $\mathrm{D}_{\mathrm{CO}_{2}}^{27} / \mathrm{D}_{\mathrm{CO}_{2}}^{10}$ was 1.17 (Table 3). This ratio for a diffusion in channels filled with air is expected to be 1.12 (Jost, 1960; Loeb, 1934).

The diffusion coefficient of $\mathrm{CO}_{2}$ in the flesh was determined using Eq. [5] and the observed values of the specific rate of respiration, internal radius, and the concentrations of $\mathrm{CO}_{2}$ in the center and under the skin. The average values of $\mathrm{D}_{\mathrm{CO}_{2}}$ in flesh were $2.5 \times 10^{-4}$ and $2.65 \times 10^{-4} \mathrm{~cm}^{2} \cdot \mathrm{s}^{-1}$ at 10 and $27 \mathrm{C}$, with a $\mathrm{D}_{\mathrm{CO}_{2}}^{27} / \mathrm{D}_{\mathrm{CO}_{2}}^{10}$ of 1.07 (Table 3). A similar range of values for the skin and flesh was also obtained in additional experiments (data not shown).

\section{Discussion}

Determining gas diffusion in bulky plant organs is rather difficult because of the uncertainties involved. For instance, the assumption that the tuber is a perfect cylinder is not strictly correct. Furthermore, the solution of Eq. [4] assumes a very long cylindri- cal shell, which is not the case for potato tubers. However, the contribution of the cylindrical bases to the concentration of $\mathrm{CO}_{2}$ in the middle of the tuber is expected to be negligible because of the appreciable resistance by the flesh to gas diffusion (Table 3 ). Furthermore, the diffusion takes place through a perforated cylindrical shell rather than the whole surface. Regardless of the methodology, experimental procedures should be developed to test the validity of the diffusivities obtained.

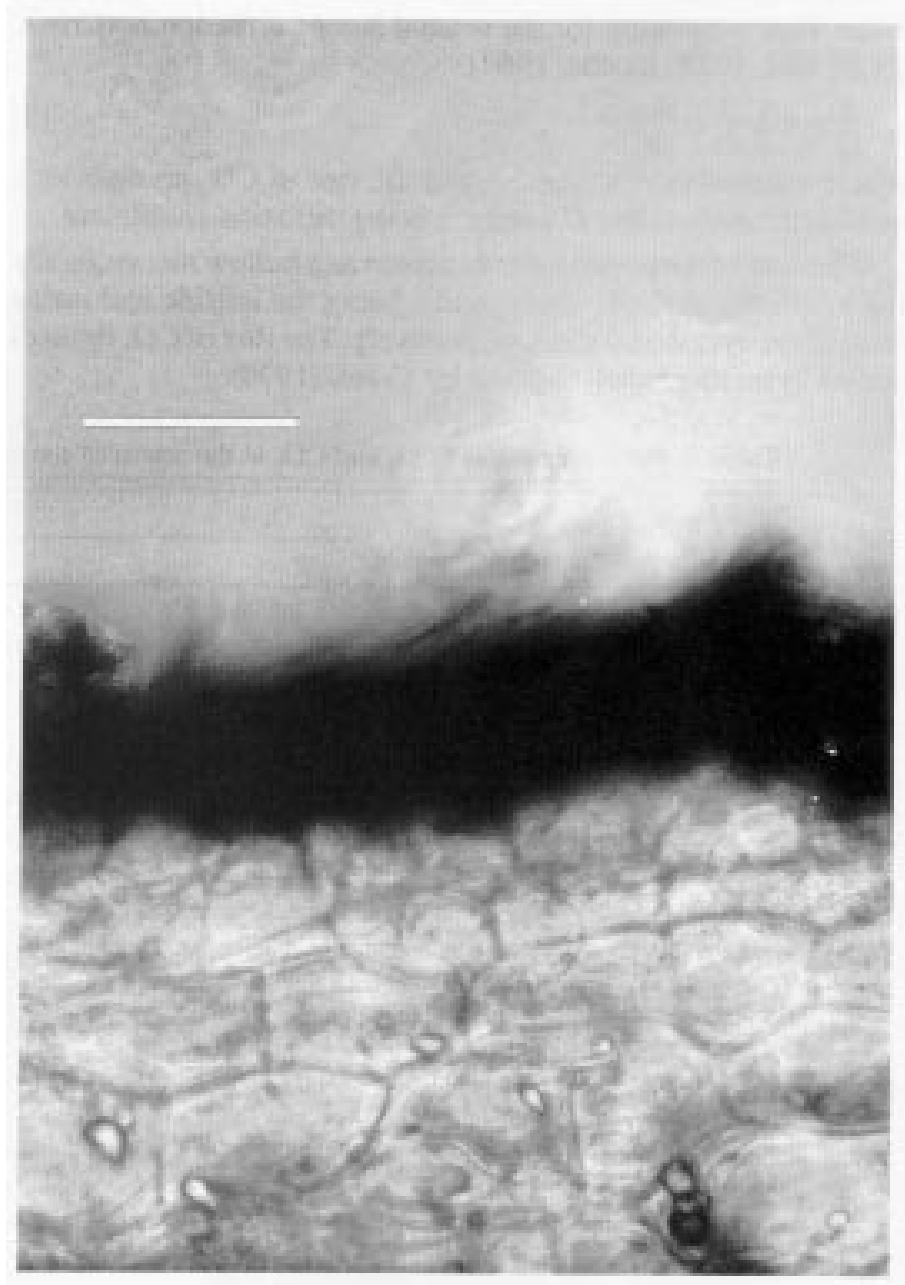

Fig. 1. A hand section of the potato tuber skin (dark area). Scale $=100 \mathrm{~nm}$. 
Table 3. Diffusion coefficient of $\mathrm{CO}_{2}$ in the skin and flesh of tubers.

\begin{tabular}{|c|c|c|c|c|c|c|}
\hline \multirow[b]{2}{*}{ Tuber } & \multicolumn{2}{|c|}{$\begin{array}{c}\text { Skin } \\
\left(10^{-7} \mathrm{~cm} \cdot \mathrm{s}^{-1}\right) \text { at }\end{array}$} & \multirow[b]{2}{*}{$\mathrm{D}_{\mathrm{CO}_{2}}^{27} / \mathrm{D}_{\mathrm{CO}_{2}}^{10}$} & \multicolumn{2}{|c|}{$\begin{array}{c}\text { Flesh } \\
\left(10^{-4} \mathrm{~cm} \cdot \mathrm{s}^{-1}\right) \text { at }\end{array}$} & \multirow[b]{2}{*}{$\mathrm{D}_{\mathrm{CO}_{2}}^{27} / \mathrm{D}_{\mathrm{CO}_{2}}^{10}$} \\
\hline & $10 \mathrm{C}$ & $27 \mathrm{C}$ & & $10 \mathrm{C}$ & $27 \mathrm{C}$ & \\
\hline 1 & 7.16 & 8.21 & 1.15 & 1.67 & 1.90 & 1.14 \\
\hline 2 & 6.73 & 9.33 & 1.39 & 2.17 & 2.23 & 1.03 \\
\hline 3 & 6.03 & 6.04 & 1.00 & 2.63 & 3.10 & 1.18 \\
\hline 4 & 6.04 & 7.97 & 1.32 & 2.68 & 2.90 & 1.08 \\
\hline 5 & 6.37 & 7.77 & 1.22 & 2.90 & 2.46 & 0.85 \\
\hline 6 & 4.19 & 5.12 & 1.22 & 2.30 & 2.67 & 1.16 \\
\hline 7 & 5.56 & 5.98 & 1.08 & 3.65 & 3.81 & 1.04 \\
\hline 8 & 7.79 & 7.62 & 0.98 & 1.96 & 2.10 & 1.07 \\
\hline Average & 6.24 & 7.26 & 1.17 & 2.50 & 2.65 & 1.07 \\
\hline
\end{tabular}

The diffusion of gases from the cell to the ambient atmosphere involves three barriers: cell membranes and walls, intercellular spaces, and the skin. The gas diffusivity through the first barrier is not known. It is fair to state that gases diffuse readily through biological membranes (Nobel, 1983). However, hydrated walls may in theory pose some resistance to gas diffusion (Chevillotte, 1973). Experimental evidence indicates that the diffusion of gases through bulky plant organs occurs in gaseous channels (Burg and Burg, 1965; Solomos, 1987). Simple calculations showed that, in apples, the presence of aqueous diffusion barriers drastically curtailed the internal concentration of $\mathrm{O}_{2}$ (Solomos, 1987). More importantly, it was shown that the diffusivities of $\mathrm{CO}_{2}$ and $\mathrm{C}_{2} \mathrm{H}_{4}$ in apples were inversely related, as expected from the ideal gas law, to the external total pressure (Burg and Burg, 1965). The existence of continuous gaseous channels in potato tubers is supported by previous microscopic observations where the intercellular spaces, 10 to $15 \mu \mathrm{m}$ in diameter, are interconnected with narrow capillary tubes $3 \mu \mathrm{m}$ in diameter (Woolley, 1962).

In view of the above evidence concerning the nature of the diffusion channels, the observed decrease in the diffusivity of $\mathrm{CO}_{2}$ through the flesh and skin from its value in air could be attributed, in part, to the tortuosity of the diffusion path but mainly to the decrease in the gaseous spaces available to gas diffusion. Woolley (1962) calculated that only $1 / 1000$ of the total flesh surface is available to gas diffusion. Burton (1950) concluded from measurements of gas flow through potato tissue cylinders that only $0.5 \%$ of the cross-sectional surface area was available to gas flow. Based on these observations, Burton (1950) calculated that the diffusion coefficient of $\mathrm{O}_{2}$ in the flesh was $2.94 \times 10^{-4} \mathrm{ml} \cdot \mathrm{cm}^{-2} \cdot \mathrm{s}^{-1}$. However, deducing diffusion coefficients from gas flow measurements requires a somewhat precise knowledge of the geometry of the capillaries because, according to Poiseuille's law of viscous flow through capillary tubes in response to pressure differential, the flow is proportional to the fourth power of the radius (Siau, 1984), whereas, the diffusion coefficient is proportional to the second power of the radius. In addition, it is questionable whether the resistance to gas flow is uniform throughout the tissue because the intercellular spaces adjacent to cut surfaces may be water-injected (Woolley, 1962). Similarly, the decrease in the diffusivity of $\mathrm{CO}_{2}$ in the skin is due to the fact that only a small fraction of the skin is permeable to gases (Burton, 1950).

The present data agree in that the diffusion channels for $\mathrm{CO}_{2}$ are gaseous in nature. For instance, it is expected that the ratio of the $\mathrm{CO}_{2}$ fluxes at 27 over $10 \mathrm{C}$ should equal the product of $1.123 \times$ $\left(\Delta \mathrm{CO}_{2}{ }^{27} / \Delta \mathrm{CO}_{2}{ }^{10}\right)$, where 1.123 is the theoretical value of $\mathrm{D}_{\mathrm{CO}_{2}}{ }^{27} /$ $\mathrm{D}_{\mathrm{CO}_{2}}^{10}$ (Jost, 1960). It may be concluded from data in Table 2 that the average value of $\mathrm{J}_{27} / \mathrm{J}_{10}$ is 3.226 , whereas, the product $1.123 \times$
Table 4. Carbon dioxide concentration ${ }^{\mathrm{z}}\left(\mu \mathrm{mol} \cdot \mathrm{cm}^{-3}\right)$ under the skin at $10 \mathrm{C}$.

\begin{tabular}{lcc}
\hline & \multicolumn{2}{c}{$\mathrm{CO}_{2} \operatorname{concn}\left(\mu \mathrm{mol} \cdot \mathrm{cm}^{-3}\right)$} \\
\cline { 2 - 3 } Tuber & Observed & Calculated \\
\hline 1 & 0.740 & 0.712 \\
2 & 0.728 & 0.700 \\
3 & 0.961 & 0.932 \\
4 & 0.776 & 0.747 \\
5 & 0.759 & 0.730 \\
6 & 1.304 & 1.280 \\
7 & 0.982 & 0.950 \\
8 & 0.742 & 0.710 \\
Average & 0.870 & 0.850
\end{tabular}

${ }^{\mathrm{z}}$ The $\mathrm{CO}_{2}$ concentration under the skin at $10 \mathrm{C}$ was calculated by inserting a) the theoretical value of the diffusion coefficient at $10 \mathrm{C}$, which was calculated from its observed value at $27 \mathrm{C}$, and b) the observed specific rate of $\mathrm{CO}_{2}$ evolution and $\mathrm{CO}_{2}$ concentration in the center into Eq. [5]. The theoretical rates of respiration at $10 \mathrm{C}$ were calculated by inserting the calculated values at $10 \mathrm{C}$ of $\mathrm{CO}_{2}$ concentration and $\mathrm{D}_{\mathrm{CO}_{2}}$ from observed values at $27 \mathrm{C}$ along with the dimensions of the tuber and $\mathrm{CO}_{2}$ concentration in the ambient atmosphere into Eq. [3].

$\left(\Delta \mathrm{CO}_{2}{ }^{27} / \Delta \mathrm{CO}_{2}{ }^{10}\right)$ is 3.257. Furthermore, we calculated the diffusion coefficient in the flesh from the observed value at $27 \mathrm{C}$. This value, along with the observed specific rates of $\mathrm{CO}_{2}$ evolution, its concentration at the center, and radius of the tuber, were inserted in Eq. [5] to calculate the $\mathrm{CO}_{2}$ concentration under the skin at 10C. The results of Table 4 indicate that the calculated values agree well with those observed. Furthermore, when the theoretical values of both $\mathrm{D}_{\mathrm{CO}_{2}}^{\text {skin }}$ and $\mathrm{CO}_{2}$ concentration under the skin (Table 4), along with the dimensions of the tuber and $\mathrm{CO}_{2}$ concentrations in the ambient atmosphere, were inserted in Eq. [3], the resultant $\mathrm{CO}_{2}$ respiration rates were similar to those observed (Table 4). In view of the fact that $\mathrm{CO}_{2}$ seems to diffuse in the skin through open gaseous pores, Eq. [3] should be multiplied by a number, L, denoting the fraction of the cylindrical surface available to gas diffusion. From the observed values of $\mathrm{D}_{\mathrm{CO}_{2}}$ at $10 \mathrm{C}$ and the known value of $\mathrm{D}_{\mathrm{CO}_{2}}^{\text {air }}\left(0.148 \mathrm{~cm} \cdot \mathrm{s}^{-1}\right)$, it is calculated that an average of 6.29 $\times 10^{-6}$ of the total cylindrical surface is occupied by the open pores.

The results of Table 1 indicate that the sum of the internal partial pressures of $\mathrm{CO}_{2}$ and $\mathrm{O}_{2}$ is equal to that of the latter in the ambient atmosphere. Thus, the partial pressure of $\mathrm{O}_{2}$ at each point along the radius would be equal to the difference between its partial pressure in the ambient atmosphere and the partial pressure of $\mathrm{CO}_{2}$ at a particular point in the tuber. Figure 2 shows that the 'Russet Burbank' tuber is well aerated and the $\mathrm{O}_{2}$ gradient between the 


\section{OXYGEN CONCETRATION ALONG RADIUS :CACULATED}

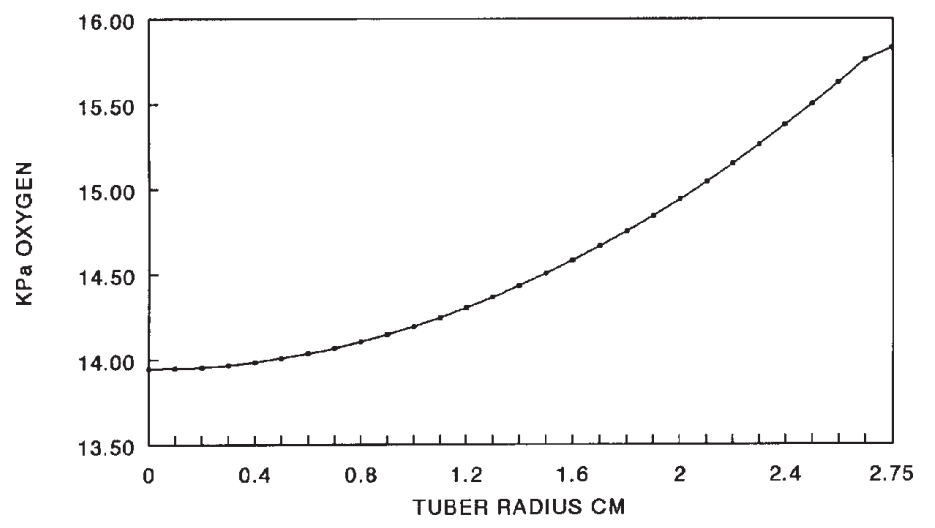

Fig. 2. Profile of $\mathrm{O}_{2}$ concentration along the radius of the tuber. The concentration of $\mathrm{O}_{2}$ was calculated as the difference between its partial pressure in the ambient atmosphere and the partial pressure of $\mathrm{CO}_{2}$ at each point along the radius. The $\mathrm{CO}_{2}$ gradient was determined by inserting in Eq. [4] the average values for $\mathrm{D}^{\text {flesh }}$, the specific rate of $\mathrm{CO}_{2}$ evolution, the radius, and the calculated values of $\mathrm{CO}_{2}$ concentration under the skin. The latter was determined by inserting the appropriate measured parameters into Eq. [3].

Table 5. Partial pressure ${ }^{\mathrm{z}}$ of $\mathrm{CO}_{2}$ at the center of the tuber.

\begin{tabular}{lccc}
\hline \hline Cultivar & Tuber & Temp $\left({ }^{\circ} \mathrm{C}\right)$ & $\mathrm{kPa}$ \\
\hline B0234-4 & 1 & 10 & $3.53 \pm 0.37$ \\
2 & & $3.77 \pm 0.30$ \\
3 & & $4.22 \pm 0.10$ \\
4 & 27 & $3.95 \pm 0.37$ \\
5 & & $12.60 \pm 0.18$ \\
6 & & $15.23 \pm 0.61$ \\
& 7 & & $16.86 \pm 0.13$ \\
& 8 & & $14.88 \pm 1.89$ \\
B0245-8 & 10 & $18.78 \pm 1.36$ \\
& 10 & & $15.23 \pm 2.12$ \\
& 1 & & $2.77 \pm 0.17$ \\
2 & & $3.19 \pm 0.25$ \\
& 3 & & $2.74 \pm 0.47$ \\
4 & 27 & $4.56 \pm 0.32$ \\
& 5 & & $12.72 \pm 0.70$ \\
6 & & $17.40 \pm 0.64$ \\
& 7 & & $15.37 \pm 0.96$ \\
& 8 & &
\end{tabular}

${ }^{\mathrm{z}}$ The values are the average of five readings $( \pm \mathrm{SD})$.

center and area under the skin is rather small, in contrast to that reported previously (Brändle, 1968). Also, Burton (1950) calculated a small $\mathrm{O}_{2}$ gradient along the tuber. However, for large tubers and high temperatures, there may be an $\mathrm{O}_{2}$ deficiency at the center of the tuber. We measured the $\mathrm{CO}_{2}$ concentration of two breeding lines, B0234-4 and B0245-8, of the breeding program at the U.S. Dept. of Agriculture, Beltsville, Md. These tubers were rather spherical, with an average radius of 4.1 and $4.5 \mathrm{~cm}$ for B0234-U and B0245-8, respectively. It may be seen from the data of Table 5 that, at high temperatures, the center of the tissue may experience partial anaerobiosis. Incidentally, both lines showed extensive development of hollow heart abnormalities. It is not clear whether there is any correlation between levels of $\mathrm{CO}_{2}$ or $\mathrm{O}_{2}$ and the development of these abnormalities.

The present data indicate that gas diffusivities in the skin and flesh of potato tubers can be determined simultaneously. Furthermore, the diffusion channels are gaseous in nature and the skin is the main barrier to gas diffusion mainly because only a small portion of the cylindrical surface is available for gas exchange. However, the flesh also presents an appreciable diffusion barrier to gas exchange. Under normal storage conditions, the tuber is well aerated and the $\mathrm{O}_{2}$ concentration at the center of the tuber is sufficient to maintain aerobic respiration because of the high affinity for $\mathrm{O}_{2}$ of the cytochrome oxidase.

\section{Literature Cited}

Banks, N.H. and S.J. Kays. 1988. Measuring internal gases and lenticel resistance to gas diffusion in potato tubers. J. Amer. Soc. Hort. Sci. 113:577-580.

Brändle, R. 1968. Die Verteilung der Sauerstoffkonzentrationen in fleischigen Speicherorganen (Apfel, Bananen und Kartoffelknollen.) Ber. Schwiez. Bot. Ges. 78:330-64.

Burg, S.P. and E.A. Burg. 1965. Gas exchange in fruits. Plant Physiol. 18:870-884.

Burton, W.G. 1950. Studies on the dormancy and sprouting of potatoes. I. The oxygen content of potato tuber. New Phytol. 49:121-34.

Burton, W.G. 1982. Postharvest physiology of food crops. Longman, London.

Burton, W.G. and W.T. Spragg. 1950. A note on the intercellular space of potato tuber. New Phytol. 49:8.

Chevillotte, P. 1973. Relation between the reaction cytochrome oxidase-oxygen and oxygen uptake in cells in vivo. The role of diffusion. J. Theoretical Biol. 39:277-295.

Crank, J. 1970. The mathematics of diffusion. Charedon, Oxford.

Hill, A.V. 1928. Diffusion of oxygen and lactic acid through tissues. Proc. Royal Soc. Biol. Ser. B 104:39-96.

Hulme, A.C. 1951. Apparatus for the measurement of gaseous conditions inside apple fruit. J. Expt. Bot. 2:65-85.

Jacobs, M.H. 1967. Diffusion processes. Springer-Verlag, New York.

James, W. 1953. Plant respiration. Oxford Univ. Press, London.

Jost, W. 1960. Diffusion in solids, liquids and gases. Academic Press, New York.

Laties, G.G. 1978. The development and control of respiratory pathways in slices of plant storage organs, p. 421-465. In: G. Kalil (ed.). Biochemistry of wooded plant tissues. Walter de Gruyter Co., Berlin.

Loeb, L.B. 1934. The kinetic theory of gases. McGraw-Hill Co., New York. p. 252-277.

Nobel, P.S. 1983. Biophysical plant physiology and ecology. Freeman, San Francisco.

Peterson, L.R., W.G. Barker, and M.J. Howard. (1985). Development and structure of tubers, p. 123-182. In: Paul H. Li. (ed.). Potato physiology. Academic Press, New York.

Siau, T.F. 1984. Transport processes in wood. Springer-Verlag, Berlin.

Solomos, T. 1987. Principles of gas exchange in bulky plant tissues. HortScience 22:766-71.

Solomos, T. and G.G. Laties. 1975. The mechanism of ethylene and cyanide action in triggering the rise in respiration in potato tubers. Plant Physiol. 55:73-78.

Wardlaw, C.W. and E.R. Leonard. 1939. Studies on tropical fruits. IV. Methods in the investigation of respiration with special reference to bananas. Ann. Bot. 3:27-42.

Woolley, J.T. 1962. Potato tuber respiration and ventilation. Plant Physiol. 37:793-798. 